\title{
Postharvest Losses from Delayed Harvest and during Common Storage of Short-day Onions
}

\author{
Marisa M. Wall ${ }^{1}$ and Joe N. Corgan ${ }^{2}$ \\ Department of Agronomy and Horticulture, New Mexico State University, Las \\ Cruces, NM 88003
}

Additional index words. quality, diseases, maturity

\begin{abstract}
A 2-year field study was conducted to evaluate the effects of maturity and storage on fresh-market onion (Allium cepa $\mathbf{L}$.) quality. Four short-day onion cultivars ('NuMex BR1', 'NuMex Sunlite', 'NuMex Starlite', and 'Buffalo') were seeded in early October each year. Bulbs were harvested at five times; the first and second harvests were when $20 \%$ and $80 \%$, respectively, of the bulbs in a plot had mature necks; the third, fourth, and fifth harvests were at 5,10, and 15 days after the second harvest date, respectively. After curing for 3 days, bulb firmness, weight, and incidence of disease were evaluated for all harvests. Bulbs were re-evaluated after 10 and 20 days storage in a shed under ambient conditions. 'Buffalo' and 'NuMex Surdite' bulbs had the lowest incidence of disease before storage. For all cultivars, average bulb weight increased and firmness decreased with delayed harvest. Percent diseased bulbs increased for all cultivars as harvest was delayed in 1991 but not in 1992. The optimum harvest time was at $80 \%$ maturity. In storage, average bulb weight and firmness decreased, and the incidence of bulb diseases increased.
\end{abstract}

Short-day onions are harvested in early summer when temperatures are often high. In the southwestern United States, harvest temperatures may exceed 38C, and heat injury, fungal rots, and bacterial decay are potential problems. These onions are rarely held in environmentally controlled storage but are commonly held past maturity in the field or stored at ambient temperatures after harvest and grading. At peak harvest times in any area, onion supply sometimes exceeds market demand, requiring growers to delay harvest or to hold bulbs in the packing shed until they can be sold. Onion harvest may also be delayed past optimum maturity if labor, handling facilities, or transportation are limited (Corgan and Kedar, 1990). Under these circumstances, fresh-market onions are subjected to additional days or weeks at high temperatures, causing postharvest losses. Our objective was to evaluate the effects of bulb maturity and storage duration under ambient conditions on fresh-market onion quality.

\section{Materials and Methods}

Four short-day onion cultivars ('NuMex BR1' (BR1), 'NuMex Sunlite' (Sunlite), 'NuMex Starlite' (Starlite), and 'Buffalo') were

Received for publication 14 May 1993. Accepted for publication 11 Jan. 1994. This research was supported by the New Mexico Dry Onion Commission and the New Mexico Agricultural Experiment Station. We thank Lucinda DeMaria and Victor Guerrero-Prieto for their technical support. The cost of publishing this paper was defrayed in part by the payment of page charges. Under postal regulations, this paper therefore must be hereby marked advertisement solely to indicate this fact.

Assistant Professor.

${ }^{2}$ Professor. direct-seeded, four rows per bed, on 9 Oct. 1990 and 8 Oct. 1991 at the Fabian Garcia Research Center at Las Cruces, N.M. The first three cultivars are yellow grano types with good bolting resistance, suitable for early fall planting (Corgan, 1984, 1988; Corgan and Holland, 1990, 1993). Buffalo is a hybrid of Japanese origin. Seedlings were hand-thinned to $10-\mathrm{cm}$ spacings in mid-Jan. 1991 and delayed until late Feb. 1992 because of wet soils and slower growth during winter.

Plots were arranged in a split-plot design with cultivars as main plots and five harvest dates as subplots. Each cultivar $\times$ harvest treatment had five replications. Main plots of each cultivar per replication were $18 \mathrm{~m}$ long and 1 $\mathrm{m}$ wide, with $0.75-\mathrm{m}$ borders on each end. Subplots for each harvest date were $1.5 \mathrm{~m}$ long and $1 \mathrm{~m}$ wide. The first harvest was performed when $20 \%$ of the bulbs in a plot had mature necks (mature necks collapse easily when

Table 1. Onion cultivar and maturity effects on average bulb weight, firmness, and disease incidence at harvest.

\begin{tabular}{|c|c|c|c|c|}
\hline \multirow[b]{2}{*}{ Variable } & \multirow{2}{*}{$\begin{array}{l}\mathrm{Wt}^{2} \\
(\mathrm{~g})\end{array}$} & \multirow{2}{*}{$\begin{array}{c}\text { Firmness } \\
(\mathrm{N})\end{array}$} & \multicolumn{2}{|c|}{ Disease incidence $(\%)$} \\
\hline & & & 1991 & 1992 \\
\hline \multicolumn{5}{|l|}{ Cultivar } \\
\hline NuMex Starlite & $263 \mathrm{a}^{y}$ & $54.4 \mathrm{a}$ & $21.5 \mathrm{a}$ & $8.4 \mathrm{a}$ \\
\hline NuMex Sunlite & $239 \mathrm{ab}$ & $53.7 \mathrm{a}$ & $4.5 \mathrm{bc}$ & $5.2 \mathrm{ab}$ \\
\hline NuMex BR1 & $235 \mathrm{ab}$ & $53.5 \mathrm{a}$ & $10.9 \mathrm{~b}$ & $7.8 \mathrm{a}$ \\
\hline Buffalo & $220 \mathrm{~b}$ & $55.3 \mathrm{a}$ & $1.9 \mathrm{c}$ & $2.0 \mathrm{~b}$ \\
\hline \multicolumn{5}{|l|}{ Harvest ${ }^{x, w}$} \\
\hline 1 & $182 \mathrm{~d}$ & $56.1 \mathrm{a}$ & $0.3 \mathrm{c}$ & $4.5 \mathrm{a}$ \\
\hline 2 & $231 \mathrm{c}$ & $56.1 \mathrm{a}$ & $4.0 \mathrm{c}$ & $6.3 \mathrm{a}$ \\
\hline 3 & $244 b c$ & $54.2 \mathrm{~b}$ & $10.5 \mathrm{~b}$ & $4.5 \mathrm{a}$ \\
\hline 4 & $265 \mathrm{ab}$ & $52.6 \mathrm{bc}$ & $13.7 \mathrm{~b}$ & $7.8 \mathrm{a}$ \\
\hline 5 & $274 \mathrm{a}$ & $52.2 \mathrm{c}$ & $20.0 \mathrm{a}$ & $6.3 \mathrm{a}$ \\
\hline
\end{tabular}

${ }^{2}$ Average bulb weight and bulb firmness data combined for 1991 and 1992. Bulb evaluations were after curing but before storage.

${ }^{y}$ Mean separation within columns by Wailer-Duncan k ratio $t$ test at $P \leq 0.05$.

'Harvests 1 and 2 were when $20 \%$ and $80 \%$ of the tops had matured, respectively. Harvests 3,4, and 5 were 5,10 , or 15 days after harvest 2 , respectively.

"Cultivar $\times$ harvest was nonsignificant at $P \leq 0.05$ for all criteria. 


\section{Results and Discussion}

Average bulb weights and firmness were similar among cultivars, although Starlite bulbs were significantly heavier than 'Buffalo' (Table 1). 'Buffalo' had the lowest percentage of diseased bulbs at harvest in both years; however, the levels were not significantly lower than those for Sunlite. In 1991, Starlite had the highest percentage of diseased bulbs. Starlite matures slightly later than 'Buffalo', Sunlite, and BR1 (Corgan and Holland, 1993), which may explain the higher bulb weight and disease incidence in Starlite. The first harvest for Starlite was 10 days later than that for the other cultivars in 1991 and 3 days later in 1992. The later harvest date allowed for increased bulb expansion and exposure to pathogens in the field.

For all cultivars, average bulb weight increased and firmness decreased as harvest was delayed (Table 1). The greatest increases in average bulb weight occurred between harvests 1 and $2(21.5 \%)$ and 3 and $4(7.8 \%)$. The time interval between harvests 1 and 2 was 6 to 8 days, depending on cultivar and year. Delaying harvest past $20 \%$ maturity allowed bulbs to increase in fresh weight; however, bulb firmness began to decrease when harvest was delayed past $80 \%$ maturity (harvest 3 ).

In 1991, but not in 1992, the incidence of diseased bulbs increased when harvest was delayed past $80 \%$. maturity (Table 1 ). For all bulbs evaluated at harvest, $7.9 \%$. had black mold, $1.1 \%$ botrytis, and $0.6 \%$ bacterial infections in 1991. In 1992, 5.3\% had black mold, $0.2 \%$ botrytis bulb rot, and $0.4 \%$ bacterial infections.

When onions were stored for 10 or 20 days under ambient shed conditions (15-34C, 76\% to $10 \% \mathrm{RH}$, respectively), average bulb weight and firmness decreased linearly with time in storage (Table 2). Weight loss ranged from $0.4 \%$ to $0.6 \%$ per day. After 10 days in storage, disease incidence ranged from $13.1 \%$ to $47.7 \%$, with an average daily increase of $2.1 \%$ in 1991 and $1.6 \%$ in 1992. Diseases found were black mold $(27.7 \%$ and $18.5 \%$ of total bulbs), bacterial infections (1.1\% and $2.3 \%$ ), and botrytis bulb rot $(2 \%$ and $0.9 \%)$ in 1991 and 1992, respectively. After 20 days in storage, the percentage of diseased bulbs ranged from $\approx 50 \%$ to $\approx 70 \%$, depending on year and cultivar. Similar results have been reported for 'Texas Grano 1015Y' onions, in which the incidence of black mold was $52 \%$ and that of slippery skin 3\% (Pseudomonas spp.) after 3 weeks of storage at 24C (Pike et al., 1989). We stored onions primarily in June, when the average daily temperature was $24.8 \mathrm{C}$, and maximum temperatures in the shed reached $34 \mathrm{C}$ in both years. The black mold pathogen, Aspergillus niger, is prolific at these temperatures (Yoo et al., 1989).

In 1991, the incidence of bulb diseases increased as harvest was delayed (Fig. 1), and this increase may have affected disease development in storage. Previous research with granex onions has shown a similar increase in storage losses with later maturity (Smittle and Maw, 1988). However in 1992, delaying har-
Table 2. Onion cultivar and storage duration effects on average bulb weight, firmness and disease incidence.

\begin{tabular}{|c|c|c|c|c|c|}
\hline \multirow[b]{2}{*}{ Cultivar } & \multirow{2}{*}{$\begin{array}{c}\text { Storage } \\
\text { (days) }\end{array}$} & \multirow{2}{*}{$\begin{array}{l}\mathrm{Wt}^{2} \\
(\mathrm{~g})\end{array}$} & \multirow{2}{*}{$\begin{array}{l}\text { Firmness } \\
(\mathrm{N})\end{array}$} & \multicolumn{2}{|c|}{ Disease incidence $(\%)$} \\
\hline & & & & 1991 & 1992 \\
\hline \multirow[t]{4}{*}{$\overline{\text { Starlite }}$} & 0 & 208 & 54.4 & 21.5 & 8.4 \\
\hline & 10 & 195 & 52.3 & 47.7 & 25.0 \\
\hline & 20 & 183 & 49.6 & 68.7 & 50.4 \\
\hline & & $\mathrm{L}^{* * *}$ & $\mathrm{~L}^{* * *}$ & $\mathrm{~L}^{* * *}$ & $\mathrm{~L}^{* * *}$ \\
\hline \multirow[t]{4}{*}{ Sunlite } & 0 & 209 & 53.7 & 4.5 & 5.2 \\
\hline & 10 & 200 & 52.8 & 25.9 & 14.2 \\
\hline & 20 & 189 & 48.8 & 53.2 & 49.7 \\
\hline & & $\mathrm{L}^{* * *}$ & $\mathrm{~L}^{* * *}$ & $\mathrm{~L}^{* * *}$ & $\mathrm{~L}^{* * *}$ \\
\hline \multirow[t]{4}{*}{ BR1 } & 0 & 186 & 53.5 & 10.9 & 7.8 \\
\hline & 10 & 177 & 52.1 & 36.9 & 25.8 \\
\hline & 20 & 171 & 49.8 & 65.1 & 50.6 \\
\hline & & $\mathbf{L}^{* * *}$ & $\mathrm{~L}^{* * *}$ & $\mathbf{L}^{* * *}$ & $\mathrm{~L}^{* * *}$ \\
\hline \multirow{4}{*}{ Buffalo } & 0 & 186 & 55.3 & 1.9 & 2.0 \\
\hline & 10 & 180 & 54.9 & 13.1 & 21.8 \\
\hline & 20 & 171 & 50.8 & 53.9 & 52.7 \\
\hline & & $\mathrm{L}^{* * *}$ & $\mathrm{~L}^{* * *}$ & $\mathbf{L}^{* * *}$ & $\mathrm{~L}^{* * *}$ \\
\hline
\end{tabular}

${ }^{2}$ Average bulb weights for 1992. Bulb firmness data combined for 1991 and 1992.

Linear (L) response significant at $P \leq 0.001$.
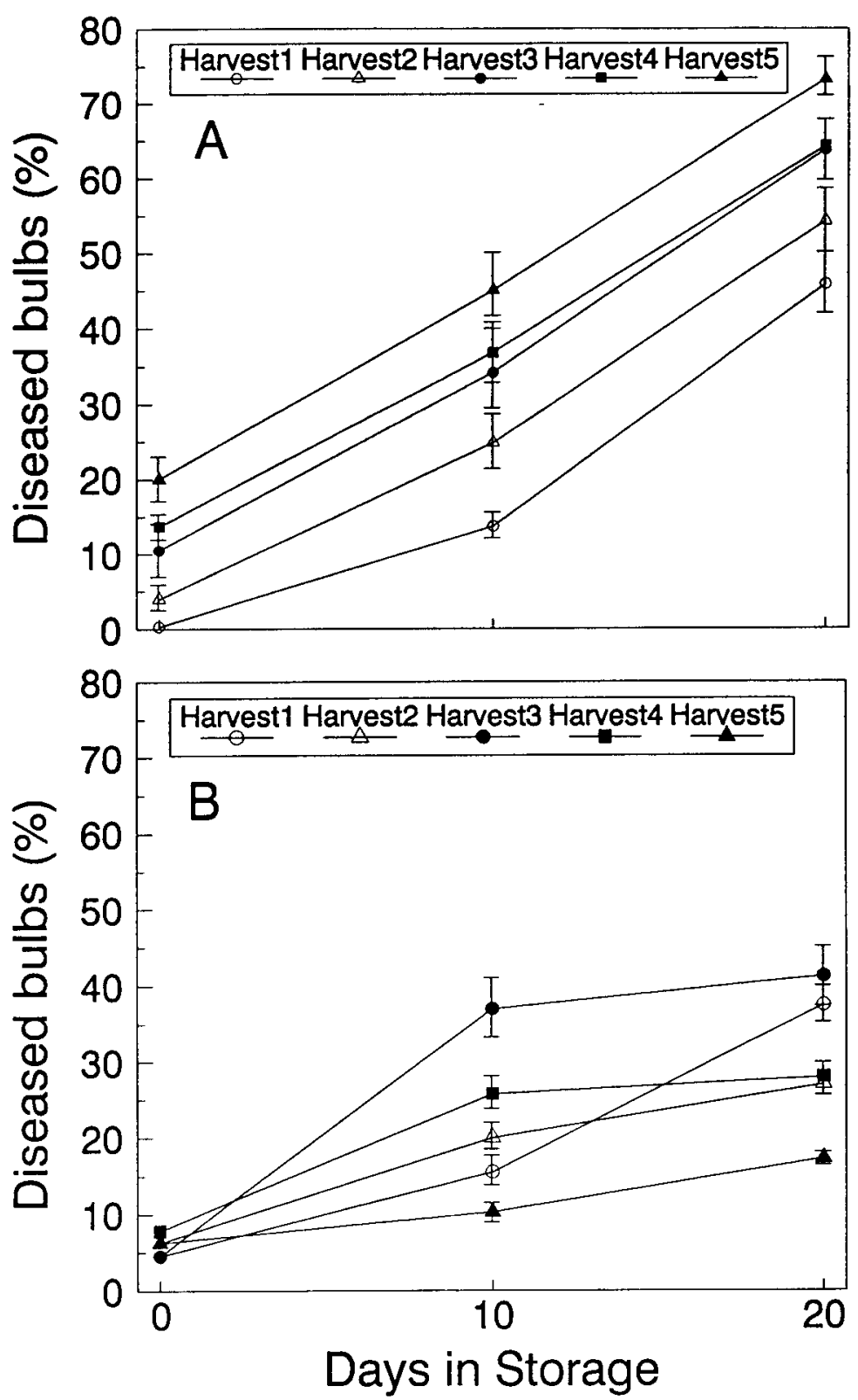

Fig. 1. Percent diseased onion bulbs in (A) 1991 and (B) 1992 after 0, 10, or 20 days of storage. Harvests 1 and 2 were performed when $20 \%$ and $80 \%$ of the tops had matured, respectively. Harvests 3,4, and 5 were 5,10 , or 15 days after harvest 2 , respectively. Data were combined for all cultivars. Vertical bars indicate the SE of the means. 
vest did not significantly affect the incidence of bulb diseases, and no clear relationship between storage diseases and maturity at harvest was evident. The percentage of diseased bulbs did increase during storage, suggesting that factors other than bulb maturity had a greater influence on disease development during storage.

Short-day onions are typically harvested when the field is $80 \%$ mature. This was the optimum harvest maturity in this study based on maximum bulb firmness, low incidence of disease, and acceptable average bulb weight. Harvesting bulbs earlier, at $20 \%$ maturity, resulted in smaller bulbs. Bulbs held in the field continued to gain weight but developed more disease in 1991. If onions are grown in fields with high levels of disease pressure, harvests should not be delayed past $80 \%$ ma- turity. Stored bulbs dessicated and quickly developed black mold; the magnitude depended on cultivar, maturity at harvest, and time in storage. Our data indicate the importance of timely harvesting and rapid handling and marketing to minimize postharvest losses of short-day onions grown in warm environments when cold storage is not used.

\section{Literature Cited}

Corgan, J.N. 1984. 'NuMex BR 1' onion. HortScience 19:593.

Corgan, J.N. 1988. 'NuMex Sunlite' onion. HortScience 213:423-424

Corgan, J. and M. Holland, 1990. Onion varieties and planting dates for southern New Mexico, New Mexico State Univ. Coop. Ext. Guide H-229.
Corgan, J. and M. Holland. 1993. 'NuMex Starlite' onion. HortScience 28:66-67.

Corgan, J.N. and N. Kedar. 1990. Onion cultivation in subtropical climates, p. 31-47. In: H.D. Rabinowitch and J.L. Brewster (eds.). Onions and allied crops. vol. II. CRC Press, Boca Raton, Fla.

Gomez, K.A. and A.A. Gomez. 1984. Statistical procedures for agricultural research. 2nd ed. Wiley-Interscience, New York.

Pike, L.M., K.S. Yoo, and T.H. Camp. 1989. A comparison between bags and boxes for shipping Texas short-day onions. HortScience 24:631-632.

Smittle, D.A. and B.W. Maw. 1988. Effects of maturity and harvest methods on storage and quality of onions. HortScience 23:141-143.

Yoo, K.S., C.R. Anderson, and L.M. Pike. 1989. Determination of postharvest losses and storage life of 'Texas Grano 1015Y' onion. J. Rio Grande Hort. Soc. 42:45-50 